the educational system of Great Britain. Discussing particular proposals such as coal and its hydrogenation, the Severn Barrage scheme and the like as contributions to Welsh reconstruction, he pointed out that such questions cannot be considered solely in terms of regional standards or local expediency. The first step in giving effect to plans for social betterment in all its aspects is to make the nation realize the extent to which its welfare depends upon coal, upon those who make it available for use, and upon those who attempt to discover how best to use it.

After reviewing the position of coal in the economic picture, Dr. North discussed the aims and objects of research. $\mathrm{He}$ deprecated the distinction between fundamental and industrial research as helpful neither to science nor to industry, and emphasized that research is a continuous process in which one step prepares the way for another. In the past, largely because of the abundance of the world's natural wealth to which Great Britain has access, industry in general prospered without much recourse to the results of research, but now as a nation we have to recognize the desirability of doing willingly in peacetime some of the things we are doing under compulsion in war-time. The only way to ensure a future adequacy of research is to create conditions affecting remuneration, prestige and equipment, in which research will be an attractive career, while those concerned with the commercial side of industry must be encouraged to develop a scientific outlook which will enable them better to appreciate and to respond to changes in the availability of raw materials, in public taste, and in technical possibilities. Dr. North urged that the right line of advance is to extend the existing facilities by more generous appropriations to the Department of Scientific and Industrial Research, more generous grants to the universities and more generous support from firms and industries that have not yet accepted their full share of the burden. Closer collaboration between research organizations is also required, and while there are in South Wales all the necessary elements for concerted research in the interest of local industry, there are few signs of general co-ordination. $\mathrm{He}$ believes that regional commissioners for the co-ordination of research might help those concerned in the industries of such a welldefined area to know what has been done or is contemplated, and at the same time keep the appropriate government department aware of the collective needs of the area.

In regard to a research programme for South Wales, Dr. North considers that a prime necessity is the vigorous prosecution of the survey of the ehemical and physical properties of all the coal seams, and the completion of the geological re-survey of the coalfield. The chemical information would indicate the nature and distribution of the various kinds of coal present, and the geological survey would indicate where and under what conditions they can be mined. Given a fair idea of the trend of industrial development, it would be possible to pay special attention to mining methods appropriate to the kinds of coal likely to be in greatest demand, and to the size and degree of purity of the coal. Co-ordinated work of this kind would help the mines to meet the increasingly exacting demands of industry; but mining research should also be encouraged to indicate the coals which can be most safely and cheaply won, leaving to industry the onus of finding efficient ways of using them. Knowledge of the varieties of coal and their potentialities must be the basis of any attempt to explore the possibilities of the underground gasification of coal, as well as of decisions concerning the kinds of new industry that can be developed and the localities in which they should be founded. Such decisions, in turn, afford guidance to those concerned in determining the position and character of new housing schemes, the facilities for access to them and the amenities required. Again, South Wales cannot afford to be unconcerned at the general lack of official interest in geological exploration, since its industries require minerals and ores not locally available.

Dr. North suggested that the basic principles should be to develop industries in which there is the greatest possible difference between the value of the raw materials used and that of the commodity or article produced, and in which the largest possible part of that difference is represented by payments to those whose services have effected the difference. Scientific and technical workers must be the guides and not the tools of the politician and financier, and the industries selected for foundation or expansion should be those which can be self-supporting at least within a reasonably short time. We should think along the lines of organic evolution, in which there is a continual reaction to changing environment by organisms which possess, in some degree, the capacity to modify or control it. An important function of the South Wales Institute of Engineers is to help create public awareness in matters appertaining to the industrial future of the region.

\section{INDUSTRIAL FATIGUE AND ABSENTEEISM}

7 HE Industrial Health Research Board has issued a pamphlet (London: H.M. Stationery Office. $3 d$.) giving a survey in non-technical language of the problems of absence from work and prevention of fatigue. Merely vague statements about the excessive amount of absenteeism are valueless. It is necessary to know how much there is, to what extent it is greater than in peace-time and the conditions leading to it.

The Industrial Health Research Board has been studying the problem throughout the war years in numbers of factories of varying size and kind, and the records have been analysed. In normal times, it was usually estimated that absence should not exceed five per cent of the possible hours of work a year. During the war years, this amount has increased and is now between six and eight per cent for men and between ten and fifteen per cent for women. There are considerable variations from factory to factory. Factories of recent growth, situated far from the homes of those who work in them, employing women unused to factory work, show an absence-rate almost twice as high as some of the old-established works within easy travelling distance of the workers' homes.

In most factories it was found that the women lost about twice as much time as the men, and married women lost up to three times as much as single women. The conditions conducive to absence include excessive hours of work, bad working conditions, unexplained idle time, wages problems, lack of cooperation between managers and workers. The factory, however, is not the whole environment of the worker; conditions outside the factory also play a part. Some of these refer to transport difficulties, 
shopping, housework and children, as well as the presence on leave of husband or son. There must also be considered the less obvious but important conditions that affect the body and the mind of the individual worker; for example, boredom, lack of understanding of the value of his work, anxiety, illhealth. As much care should be taken of the health of the industrial worker as is taken of the health of the men and women in the Fighting Forces.

The accumulated effects of war-time conditions have caused in many workers a state vaguely labelled industrial fatigue, of which one expression is in absenteeism.

During a war it is impossible to avoid making heavy demands on people's energy ; but it should have been possible, if adequate use had been made of the available knowledge, to have prevented some of the worst effects. Unfortunately, for diagnostic purposes the effects of fatigue and those of boredom are similar, namely, lowered output, inferior quality of work, increase of accidents, discontent, and some physical symptoms of ill-health. Fatigue and boredom also affect one's attitude to the work and to the War. The over-tired or very bored worker becomes despondent or indifferent, and tends to lose his sense of proportion in regard to himself and his surroundings, as well as to the course of the War. The remedies are not really difficult to deduce or to make effective.

The weekly hours should not exceed 60 for men and 55 for women, and even these are too high for certain classes of work. The week-end break is important. There should be adequate rest pauses within each spell of work. Attention should be given to the design and speed of machines, and to the selection and training of people for the jobs they are best fitted to undertake. Good working conditions including canteens, and rest and recreation rooms, help to decrease fatigue and boredom, and music is a very popular antidote.

The pamphlet is most attractively printed, produced and illustrated.

\section{NATURAL HISTORY OF THE MINNOW}

$\mathrm{M}$ ISS WINIFRED FROST has done good work on the biology and natural history of the minnow Phoxinus phoxinus (J. Animal Ecol., 12, No. 2 ; Nov. 1943). Taking Lake Windermere and one of its affluent streams, the River Brathay, as headquarters, the minnow has been studied in detail for two years. The investigation deals with its habits, growth, food and reproduction. Minnows are active and pelagic in both lake and stream from April until October, and migrate into deeper water where they are relatively passive and hidden under stones from November to March. They breed from May until July, sexual maturity in a few being reached at the end of the first year : the majority of those in their second year and all older fish are mature.

Length frequency curves supported by scale examination indicate that there are certainly three-year classes, and suggest the possibility of a fourth. The feeding habits have been studied intensively and it is found that in the lake, although a variety of feod is taken, planktonic Crustacea, particularly Cladocera, form the chief food and these are also much eaten by the other fish. The supply of these organisms is, however, so large that it seems unlikely that the minnow is a serious competitor for food in this com- munity, especially because of its inshore habits. In the river, Algæ are eaten, a much larger proportion of insect larvæ and less Cladocera and copepods. Much of the food here is similar to that of the young brown trout, and competition is likely. As to enemies, there are many, for the minnow is eaten by a few trout and many perch but not much by the pike. Eels also eat it and it forms part of the diet of the brown trout.

In Windermere and similar large lakes the conclusion is that it is unlikely that the minnow is a serious competitor for food, and it is of itself an appreciable source of food for larger fish. In running water inhabited primarily by salmon and trout the possibility of serious competition is great. So far as fishery conservation is concerned it is concluded that in general, provided the fish population is balanced with active predators to keep their numbers in check, it may be said that minnows are not inimical to a fishery. If, however, the balance is disturbed in favour of fish such as salmon and trout to the exclusion of the more active predatory fish, the minnow may multiply and become a menace.

\section{JUTE STUDIES}

$\mathrm{R}^{\mathrm{B}}$ ECENTLY there have been several Indian publications upon the anatomy of jute (Corchorus) with special reference to the fibre production and development. Such studies are to be welcomed as affording a basis for the practical improvement of varieties and for modification of extraction and preparation methods.

An earlier paper by Prof. B. C. Kundu (J. Indian Bot. Soc., 21, 93 ; 1942) has been followed by Agricultural Research Memoir No. 1 from the Indian Central Jute Committee. This confirms the work of Kundu in the main particulars, though the authors, S. S. Ghosh, K. R. Rao and J. S. Patel do not agree that the original protophloem of jute is secondary in origin. Discrepancies here may be associated with the age of the shoot apex examined; certainly Kundu's figures of the early procambial strands are striking in their demonstration of the early growth being entirely by longitudinal divisions, though it may not necessarily be solely with radial seriation as in the case of cambial activity.

In $C$. capsularis these authors record the presence of a distinct periderm, not seen by Kundu, much of whose material was grown under greenhouse conditions in England; the authors note how this periderm, as also the free development of adventitious roots at the base of plants frequently flooded during growth, may prove a deleterious influence upon the ready separation of the fibre during retting.

As Agricultural Research Memoir No. 2, Messrs. J. S. Patel and S. S. Ghosh have published a preliminary study of the anatomy of retted jute. These studies have shown how progressive the isolation of the fibre strands may be; thus they may be free in the top portion of the stem in five-six days, in the middle of the stem in nine-twelve days and at the base only after fifteen-twenty days. Heavily lignified fibres resist retting, while near nodes, injuries, etc., retting is usually delayed (this was exemplified, in the case of nodes, in some photographs communicated by J. H. Priestley to the late Dr. S. G. Barker, J. Textile Inst., $30,273 ; 1939)$. These retting studies contain some preliminary notes on retting organisms; but these need extension by isolation and culture of the organisms by the usual methods. 